\title{
Perineural Hemangioma
}

National Cancer Institute

\section{Source}

National Cancer Institute. Perineural Hemangioma. NCI Thesaurus. Code C6526.

A hemangioma arising from perineural tissues. 